\title{
IDENTIFIKASI TOTAL COLIFORM, E.COLI DAN SALMONELLA SPP. SEBAGAI INDIKATOR SANITASI MAKANAN KANTIN DI LINGKUNGAN KAMPUS TERPADU UNIVERSITAS ISLAM INDONESIA
}

\author{
Suphia Rahmawati'), Aulia Ulfa Farahdiba'), Oki Alfan'), Raditya Bill Adhly ${ }^{1)}$ \\ 1) Universitas Islam Indonesia (UII), Prodi Teknik Lingkungan, Jl. Kaliurang KM 14,5, Besi, Sleman, Yogyakarta \\ ${ }^{2)}$ Universitas Pembangunan Nasional Veteran Jawa Timur, Jalan Raya Rungkut Madya, Gunung Anyar, Surabaya \\ suphia.rahmawati@uii.ac.id
}

\begin{abstract}
Abstrak
Salah satu cara untuk mengetahui tingkat higiene dan sanitasi makanan adalah melalui analisis mikrobiologis yaitu dengan uji keberadaan E. coli dan Salmonella spp. Sampel makanan masak dan mentah, air minum, alat masak dan penjamah makanan yang berasal dari dua kantin Universitas Islam Indonesia Yogyakarta diambil dan diuji dengan metode Jumlah Perkiraan Terdekat (JPT) atau Most Probable Number (MPN) untuk Total Coliform sedangkan E. coli diidentifikasi menggunakan metode APHA 9223 B dengan IDEX Colielert. Media Salmonella Shigela Agar digunakan sebagai media selektif untuk uji kualitatif Salmonella sp. Hasil analisis menunjukkan bahwa $27 \%$ sampel memiliki Total Coliform diatas 2400MPN/100ml dan dan tidak dirdeteksi E. coli pada semua sampel. Sedangkan uji kualitatif Salmonella spp terdeteksi 16\% dari total sampel. Berdasarkan hasil observasi, konstruksi gedung kantin sudah cukup baik akan tetapi fasilitas penunjang sanitasi kurang memadai. Sedangkan berdasarkan wawancara, pengetahuan tentang sanitasi dan higiene perseorangan karyawan kantin dinyatakan kurang.
\end{abstract}

Kata Kunci : E.Coli, Salmonella, sanitasi kantin

\section{Abstract}

Microbiological analysis as the presence of E. coli and Salmonella spp. has been used as one tool to determine food hygiene and sanitation. The samples, such as food material, cooked food, drinking water, cooking utensils and swabs samples food handlers, were collected from two canteens in Universitas Islam Indonesia in Yogyakarta city. Most Probable Number (MPN) method was used to determined Total coliform while for E. Coli was determined based on APHA 9223B method using IDEX Colilert. In the other hand, the selective medium applied for qualitative testing of Salmonella sp. The results showed that $27 \%$ of samples had detected Total Coliform above 2400MPN/100ml however E.coli was not detected in all samples. Salmonella spp. as qualitative test was detected in $16 \%$ of the total samples. According to observation and questionnaire, construction of canteen are meet the standard however sanitation facilities are inadequate. In addition, the canteen employees knowledge of sanitation and personal hygiene were still lacking.

Key words : Cateen sanitation, E.Coli, Salmonella

\section{PENDAHULUAN}

Pada usaha penyediaan makanan selain faktor kuantitas yang harus dipenuhi untuk mencukupi kebutuhan konsumen, faktor yang tidak kalah pentingnya adalah faktor kualitas makanan yang erat kaitannya dengan higiene dan sanitasi. Kasus keracunan makanan atau penyakit bawaan makanan sering terjadi tanpa memperdulikan golongan masyarakat (usia, jenis kelamin, tingkat ekonomi) maupun lokasi geografis (Miskimin et al., 1976). Penyebab keracunan makanan sebagian besar disebabkan oleh aktivitas mikroorganisma yang ada di makanan yang menandakan tingkat higiene dan sanitasi yang kurang baik. Berdasarkan data Centers for Disease Control and Prevention (CDC) penyakit bawaan makanan di Amerika mencapai 76 juta kasus 5000 orang diantaranya meninggal 
dunia setiap tahun. Sebanyak $81 \%$ dari kasus disebabkan oleh mikroorganisma patogen yang tidak diketahui (Medeiros et al., 2001).

Di Indonesia, persyaratan higiene makanan jajanan telah diatur berdasarkan Kepmenkes No.924/Menkes/SK/VII/2003, walaupun demikian berdasarkan data yang dirangkum oleh BPPOM Indonesia pada bulan Oktober sampai Desember 2015, terdapat 20 insiden keracunan makanan dimana 13 insiden berasal dari makanan olahan jasa boga dan 3 insiden disebabkan oleh makanan olahan PKL (BPOM, 2015). Untuk mengetahui tingkat higiene dan sanitasi makanan salah satu caranya adalah menggunakan metode analisis mikrobiologis. Bakteri yang pada umumnya dijadikan indikator dalam industri makanan adalah bakteri kelompok Coliform (ILSI Europe, 2012) dan salah satu spesiesnya yaitu Escherichia Coli (E. coli) digunakan sebagai indikator kontaminasi fekal (Lawley et al., 2008).

Bakteri patogen lain yang dikenal dapat menyebabkan penyakit bawaan makanan adalah Salmonella. Jika makanan mengandung mengandung beberapa jenis genus dan spesies bakteri ini dalam jumlah tertentu maka dapat menyebabkan terjadinya gangguan pencernaan (Suwandono et al., 2005; Roberts dan Greenwood, 2003). Menurut Miskimin et al. (1976), Salmonella spp. Termasuk tiga besar jenis bakteri penyebab keracunan makanan di Amerika serikat. Kemudian pada tahun 2009 di Connecticut USA, sejumlah pengunjung suatu resepsi mengalami keracunan akibat memakan salad kentang. Di Indonesia diperkirakan terdapat 60.000 sampai 1.300.000 kasus demam tifoid dan menyebabkan sedikitnya 20.000 kematian per tahun yang disebabkan oleh Salmonella (Suwandono et al., 2005).

Pengetahuan dan perilaku penjamah (penyedia) makanan berhubungan erat sanitasi makanan dan minuman. Penyedia makanan memegang peranan penting dalam pencegahan keracunan makanan mulai dari proses produksi makanan (penyediaan) sampai dengan distribusi makanan (Walker et al., 2003). Higiene perseorangan (personal hygiene) penjamah makanan juga dapat berpengaruh terhadap higiene makanan. Higiene perseorangan adalah tindakan pemeliharan kebersihan dan kesehatan seseorang untuk kesejahteraan fisik dan psikis (Tarwoto dan Wartonah, 2004) sedangkan menurut Departemen Kesehatan Republik Indonesia (2000) perawatan diri adalah kemampuan dasar manusia dalam memenuhi kebutuhannya guna mempertahankan kehidupannya, kesehatan dan kesejahteraan sesuai dengan kondisi kesehatannya. Penjamah makanan yang memiliki higiene perseorangan yang buruk dapat menyebabkan kontaminasi makanan (Buccheri et al., 2007).

Berdasarkan uraian diatas, maka penelitian ini dilakukan untuk mengetahui tingkat higiene dan sanitasi makanan siap saji yang berasal dari kantin yang berada di lingkungan Kampus Terpadu Universitas Islam Indonesia (UII). Studi ini belum pernah dilakukan sebelumnya dan dapat digunakan 
sebagai masukan bagi pengelola kampus UII. Analisis Total Coliform, E. coli dan Salmonella spp. Digunakan sebagai indikator mikrobiologis juga pengetahuan dan perilaku penjamah (penyedia) makanan terhadap higiene dan sanitasi makanan.

\section{METODE PENELITIAN}

\subsection{LOKASI SAMPLING}

Penelitian dilakukan pada lima penjaja makanan yang terdapat di dua lokasi, yaitu kantin yang berada di Gedung Fakultas Teknik Sipil dan Perencanaan (satu penjaja) sedangkan kantin lainnya berlokasi di Kantin Terpadu yang terdiri dari 4 penjaja makanan. Penelitian dilakukan pada Juli- Agustus 2016 pengambilan sampel dilakukan duplo, sedangkan kondisi eksisting kantin diperoleh dengan data kuesioner dan observasi.

\subsection{ANALISIS SAMPEL}

Untuk sampel makanan, 50 gram sampel ditimbang pada kondisi aseptik sebelum dimasukkan kedalam gelas piala yang sudah disterilkan terlebih dahulu. Kemudian ditambahkan dengan larutan peptone sebanyak 0.1 dalam 100mL aquades. Kemudian dicampur hingga homogen dan didiamkan selama 5 menit. Hal serupa dilakukan untuk sampel usapan tangan penjamah makanan.

Metode pemeriksaan Total Coliform dan E. coli sampel makanan dan sampel yang berasal dari penjamah makanan menggunakan metode Jumlah Perkiraan Terdekat (JPT) atau Most Probable Number (MPN) menggunakan fermentasi tabung banyak yang terdiri dari dua tahap yaitu Tes Perkiraan (Presumtive Test) dan Tes Penetapan (Confirmed Test) (Cappucino dan Sherman, 2002). Sedangkan untuk sampel air penetapan total coliform dan E. coli dilakukan dengan metode APHA 9223B (EPA, 1998; Standard Method, 1998) menggunakan IDEX Colilert. Metode analisis secara rinci adalah sebagai berikut:

\section{Tes perkiraan}

Sampel diinokulasi secara steril pada tabung durham dengan media berbeda yaitu laktosa ganda dan laktosa tunggal dengan volume sampel berturut-turut 10, 1 dan $0.1 \mathrm{ml}$, kemudian diinkubasi pada suhu $37^{\circ} \mathrm{C}$ selama 24 sampai 48 jam. Tabung yang menghasilkan gas dan asam menunjukkan hasil tes yang positif.

\section{Tes penetapan}

Tes penetapan dilakukan untuk menentukan Total Coliform dan E. coli, dengan menginokulasikan sampel yang menunjukkan hasil positif atau ragu-ragu pada tes perkiraan pada tabung reaksi yang 
berisi media Eosin Methylene Blue (EMB) agar steril. Seluruh sampel diinkubasi pada suhu $42^{\circ} \mathrm{C}$ selama 24 jam. Total coliform ditetapkan dengan menggunakan tabel JPT (MPN).

Pada metode Colilert, reagen dicampurkan dengan sampel yang akan diperiksa kemudian dituangkan pada Quanti-Tray (counts $<1-200 \mathrm{MPN} / 100 \mathrm{ml}$ ), masukkan kedalam inkubator selama 18 jam pada suhu $35^{\circ} \mathrm{C}$. Hasil berwarna kuning menunjukkan Total Coliform sementara hasil hasil berwarna kuning dengan fluorescent menunjukkan hasil positif $E$. coli.

Metode pemeriksaan Salmonella-shigella merupakan tes kualitatif yang menyatakan positif dan negatif sampel. Sampel dicampur dengan $0.1 \%$ pepton dihancurkan dengan blender kemudian diinokulasi kedalam campuran Trathionate Broth dan Selenite Broth. Suspensi tersebut kemudian diinokulasikan pada permukaan Brilliant Green Agar dan Salmonella Shigela Agar. Inkubasi sampel selama 24-48 jam pada suhu $37^{\circ} \mathrm{C}$ untuk Brilliant Green Agar dan 18 jam untuk Salmonella Shigela Agar. Hasil yang positif akan menunjukkan adanya koloni yang hidup pada agar tersebut.

\subsection{OBSERVASI DAN WAWANCARA}

Untuk mengetahui kondisi fisik kantin, observasi dilakukan berdasarkan kriteria yang tercantum dalam Keputusan Menteri Kesehatan Republik Indonesia Nomor 1098/ Menkes/ SK/ VII/ 2003. Observasi hanya fokus pada faktor utama seperti kondisi bangunan, konstruksi, fasilitas sanitasi, kondisi ruang pengolahan, dan penyajian makanan. Tiap faktor memiliki beberapa variabel yang terdiri dari beberapa komponen penilaian dengan bobot tertentu. Sedangkan katagori penilaian terbagi menjadi empat katagori yaitu: sangat baik, baik, cukup, dan buruk sesuai nilainya. Untuk mengetahui pengetahuan tentang higiene perseorangan dan pengatahuan tentang sanitasi makanan, dilakukan wawancara terhadap penjamah makanan (penjaja makanan) baik tukang masak, pelayan maupun kasir. Jenis pertanyaan yang diajukan adalah pertanyaan tertutup meliputi faktor-faktor yang berhubungan dengan higiene perseorangan dan sanitasi makanan.

\subsection{ANALISIS DATA}

Data hasil uji mikroorganisma dicatat dan dikelompokkan berdasarkan jenis sampelnya. Data ini kemudian diolah dengan metode statistik deskriptif menggunakan grafik atau diagram menggunakan software Microsoft Excel versi 2010 untuk memudahkan membandingkan antar kelompok sampel. Sedangkan untuk data observasi dan kuesioner akan dikelompokkan berdasarkan parameter observasi dan jenis pertanyaan. Hasil observasi diolah dengan mengalikan katagori penilaian dengan bobot masing-masing komponen penilaian. Kemudian hasilnya dinyatakan dalam prosentase terhadap nilai totalnya. Sedangkan untuk hasil wawancara, diolah dalam bentuk tabel dan grafik. Hasil observasi 
dan kuesioner juga akan digunakan untuk mendukung analisa hasil uji mikroorganisma. Seluruh data akan diolah untuk membandingkan kondisi higiene dan sanitasi antara lokasi sampling (kantin) terpilih dengan metode skoring.

\section{HASIL DAN PEMBAHASAN}

\subsection{KONSTRUKSI BANGUNAN}

Faktor-faktor yang ditinjau pada penelitian ini meliputi kondisi lantai, dinding, ventilasi dan faktor lainnya. Berdasarkan hasil observasi skor penilaian kondisi eksisting bangunan atau konstruksi pada Tabel 1 dan persentase skore penilaian dapat dilihat pada Gambar 1.

Tabel 1. Penilaian terhadap kondisi eksisting konstruksi kantin

\begin{tabular}{llccccc}
\hline \multirow{2}{*}{ No } & \multirow{2}{*}{ Konstruksi } & FTSP & \multicolumn{4}{c}{ Kantin Terpadu } \\
\cline { 4 - 7 } & & $\mathbf{X}$ & $\mathbf{A}$ & $\mathbf{B}$ & $\mathbf{C}$ & $\mathbf{D}$ \\
\hline 1 & Lantai & 9 & 3 & 3 & 3 & 3 \\
2 & Dinding & 10 & 4 & 7 & 7 & 7 \\
3 & Ventilasi & 5 & 8 & 8 & 8 & 8 \\
4 & Intensitas Cahaya & 5 & 8 & 8 & 8 & 8 \\
5 & Atap & 10 & 8 & 8 & 8 & 8 \\
6 & Langit-langit & 10 & 6 & 6 & 6 & 6 \\
\hline & Total (60) & $\mathbf{4 9}$ & $\mathbf{3 7}$ & $\mathbf{4 0}$ & $\mathbf{4 0}$ & $\mathbf{4 0}$ \\
\hline
\end{tabular}

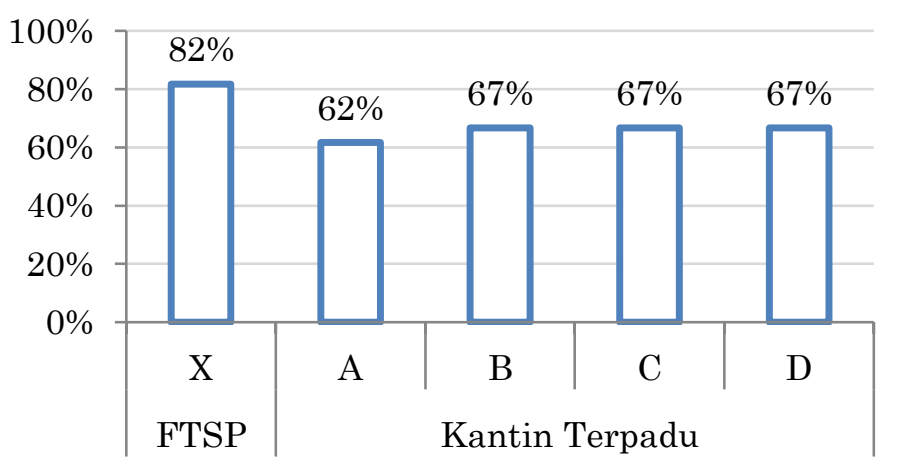

Gambar 1. Persentase penilaian kondisi eksisting konstruksi Kantin

Kantin yang berada di Kantin Terpadu seluruhnya berada di bawah 75\%, sedangkan kantin yang berada di Gedung FTSP memiliki skor diatas $80 \%$. Hal ini disebabkan oleh kondisi lantai dan dinding pada kantin yang berada di Kantin Terpadu tidak rata, tidak kedap air dan kurang bersih. Untuk katagori pencahayaan dan ventilasi, kantin $\mathrm{X}$ tertutup sehingga kondisi lebih gelap dibandingkan dengan kantin yang berada di Kantin Terpadu. 


\subsection{FASILITAS SANITASI}

Fasilitas sanitasi ditinjau dari beberapa parameter yaitu ketersediaan air bersih, saluran air limbah, toilet, tempat sampah, bak cuci tangan, bak cuci peralatan, bak cuci bahan makanan dan tandon air. Tabel 2 menyatakan penilaian terhadap kondisi eksisting fasilitas sanitasi kantin. Sedangkan Gambar 2 merupakan prosentase penilaian kondisi eksisting fasilitas sanitasi.

Tabel 2. Penilaian terhadap kondisi eksisting fasilitas sanitasi kantin

\begin{tabular}{l|l|c|c|c|c|c}
\hline \multirow{2}{*}{ No } & \multirow{2}{*}{ Fasilitas Sanitasi } & \multirow{2}{*}{ FTSP } & \multicolumn{5}{|c|}{ Kantin Terpadu } \\
\cline { 4 - 7 } & & & A & B & C & D \\
\hline 1 & Air bersih & 8 & 8 & 8 & 8 & 8 \\
2 & Saluran air limbah & 7 & 10 & 10 & 10 & 10 \\
3 & Toilet & 10 & 7 & 7 & 7 & 7 \\
4 & Tempat sampah & 8 & 8 & 8 & 8 & 8 \\
5 & Bak cuci tangan & 10 & 7 & 7 & 7 & 7 \\
6 & Bak cuci peralatan & 4 & 2 & 2 & 2 & 2 \\
7 & Bak cuci bahan makanan & - & - & - & - & - \\
8 & Tandon air & 10 & 10 & 10 & 10 & 10 \\
\hline \multicolumn{2}{c}{ Total $(80)$} & $\mathbf{5 7}$ & $\mathbf{5 2}$ & $\mathbf{5 2}$ & $\mathbf{5 2}$ & $\mathbf{5 2}$ \\
\hline
\end{tabular}

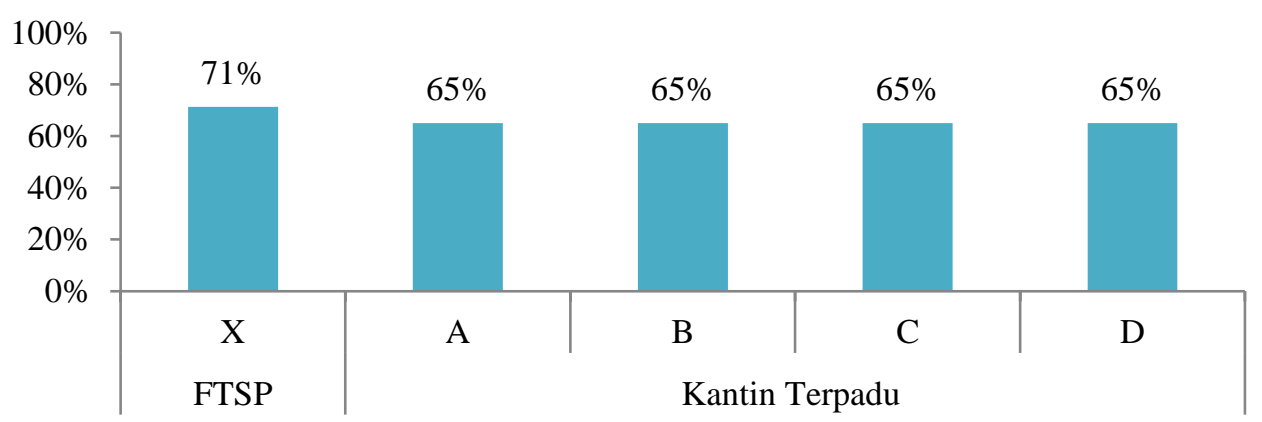

Gambar 2. Persentase penilaian kondisi eksisting fasilitas sanitasi

Fasilitas air bersih kantin bersumber dari Perusahaan Daerah Air Minum (PDAM) yang mampu memenuhi kebutuhan kantin, baik dari segi kualitas maupun kuantitas. Saluran air limbah tiap kantin terbuat dari bahan kedap air dan mengalir dengan lancar dilengkapi dengan grease trap kecuali kantin di FTSP (Tabel 2). Toilet pada kantin terpadu terletak dibagian belakang kantin sehingga terpisah dari dapur kantin. Air bersih, jamban, dan sabun tersedia untuk cuci tangan. Walaupun demikian kondisi toilet tidak bersih. Sedangkan toilet pada kantin FTSP memiliki kondisi yang lebih baik (lebih bersih).

Tempat sampah tersedia di semua kantin berupa kantong plastik atau tempat sampah plastik yang dilapisi oleh kantong plastik. Akan tetapi tempat sampah ini tidak ditutup sehingga lalat dengan mudah hinggap. Pengambilan sampah dilakukan pada waktu sore hari oleh pihak ketiga. Fasilitas 
cuci tangan (washtaffel) tersedia dan berfungsi dengan baik di setiap lokasi kantin. Sabun cuci tangan hanya tersedia pada lokasi kantin FTSP sedangkan pada kantin Terpadu tidak tersedia.

Fasilitas bak cuci alat masak dan bak cuci bahan makanan di semua kantin tidak terpisah. Bak cuci pada kantin di FTSP terbuat dari bahan stainless steel, sehingga mudah dibersihkan dan tidak mudah berkarat. Sementara bak cuci pada pada kantin Terpadu terbuat dari adukan semen yang dilapisi dengan keramik. Kondisi bak cuci di kantin FTSP lebih bersih dan rapi dibandingkan dengan bak cuci yang ada distiap penjaja di Kanti Terpadu.

Secara umum, persyaratan sanitasi kantin baik ditinjau dari segi kondisi bangunan dan fasilitas sanitasi telah tersedia walaupun secara kualitas belum semua memenuhi syarat. Walaupun demikian untuk penyediaan makanan kelima kantin tersebut masih belum memenuhi syarat karena tempat penyajian makanan dan penyimpanan makanan tidak tertutup sehingga dapat dengan mudah dihinggapi lalat atau terkontaminasi oleh zat lain.

\subsection{PENGETAHUAN HIGIENE PERSEORANGAN DAN SANITASI KANTIN}

Pengetahuan higiene perseorangan dan sanitasi kantin diperoleh dari data kuesioner terhadap penjamah makanan (karyawan). Higiene perseorangan menyangkut kondisi dan kebiasaan pengelola makanan dalam menyiapkan makanan misalnya: kondisi kesehatan, kebersihan kuku, penggunaan masker, celemek, dsb. Sementara pengetahuan sanitasi kantin misalnya tempat penyimpanan makanan, tempat memasak makanan, tempat penyajian makanan, sumber air untuk pengolahan makanan, pengangkutan makanan, peletakan tempat sampah dan pengangkutan sampah. Berikut ini adalah skore pengetahuan higiene perseorangan dan kondisi sanitasi (Gambar 3).

Pada Gambar 3 dapat dilihat bahwa skoring pengerahuan tentang higiene perseorangan tertinggi terdapat pada pengelola kantin X (89\%), sedangkan yang terendah pada pengelola kantin B yaitu 46\%. Secara umum, pengetahuan pengelola kantin (penjamah makanan) masih berada di bawah $50 \%$. Pada umumnya penjamah makanan masih terus bekerja walaupun pada saat itu sedang sakit. Penjamah makanan menggunakan celemek pada saat mengolah makanan, akan tetapi semua tidak menggunakan masker dan sarung tangan pada saat mengolah makanan.

Pengetahuan mengenai kondisi sanitasi kantin untuk setiap kantin diatas $65 \%$ akan tetapi masih berada dibawah $80 \%$. Skore tertinggi terdapat pada Kantin A sementara skor terendah diperoleh pada kantin B (Gambar 3). Berdasarkan wawancara yang dilakukan kepada pengelola kantin, makanan pada kantin X, B dan C diolah di rumah pemilik kantin kemudian dibawa menggunakan tempat yang tertutup untuk menghindari kontaminasi. Kemudian makanan tersebut dipanaskan sebelum dijual. 
Sedangkan kantin A dan D mengolah makanan langsung di lokasi kantin sehingga makanan yang disajikan lebih segar. Menurut Mirawati et al. (2013), sampel (makanan) dapat terkontaminasi selain disebabkan karena kebersihan alat, wadah tempat berjualan, kondisi lingkungan tempat berdagang, disebabkan juga oleh higiene pedagangnya. Secara umum pengetahuan tentang kondisi sanitasi harus lebih ditingkatkan sehingga dapat mencegah kontaminasi makanan yang bersumber dari buruknya kondisi sanitasi.

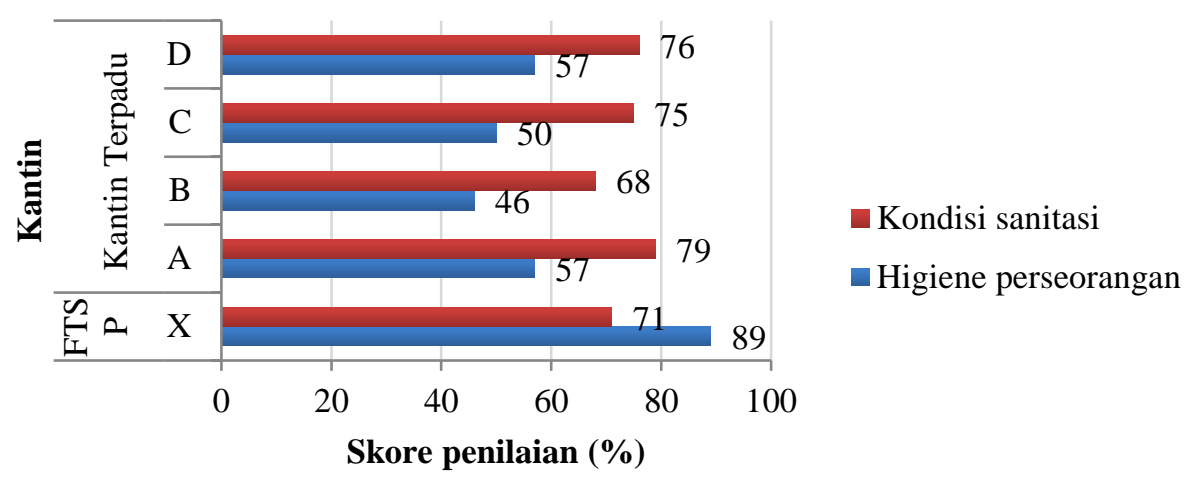

Gambar 3. Persentase skoring pengetahuan tentang higiene perseorangan dan kondisi sanitasi kantin

\subsection{TOTAL COLIFORM DAN E. COLI}

Sampel yang diambil terdiri dari sampel makanan, minuman, sumber air bersih, penjamah makanan, dan peralatan masak. Hasil uji peneguhan dapat dilihat pada Tabel 3.

Tabel 3. Hasil uji peneguhan pada sampel makanan dari setiap kantin

\begin{tabular}{cccccc}
\hline Sampel & $\mathbf{5}$ & Jumlah MPN/100ml pada Kantin & D \\
\hline Makanan Masak & 23 & 1430 & $2400+$ & 1247 & $2400+$ \\
Makanan Mentah & 1750 & 1248 & $2400+$ & 1750 & $2400+$ \\
Air Minum & $2400+$ & 1430 & $2400+$ & 1750 & $2400+$ \\
Air Keran & 26 & 55 & $2400+$ & 40 & 1750 \\
Tangan Juru Masak & 125 & 1320 & 1430 & 16 & 1320 \\
Peralatan Makan & 780 & 90 & 1750 & 29 & 1430 \\
\hline
\end{tabular}

Berdasarkan Tabel 3 dapat diketahui bahwa sampel makanan mentah, air minum. dan makanan masak memiliki jumlah MPN/100mL melebihi 2400 (>80\% sampel). Sedangkan sampel air keran (air bersih), dan peralatan makan jumlah total coliform bervariasi. Sementara sampel dari swab tangan juru masak 60\% sampel memiliki jumlah total Coliform >2400 MPN/100mL. Semua sampel air minum dan air bersih memiliki jumlah Coliform diatas 1000MPN/100mL. Hal ini tidak sesuai dengan Peraturan Menteri Kesehatan Republik Indonesia Nomor 492/ MENKES/ PER/ IV/ 2010 tentang persyaratan kualitas air minum dimana jumlah maksimum yang diperbolehkan adalah 0 MPN/100 
ml. Sampel makanan mentah yaitu mentimun dan kubis memiliki jumlah total coliform tinggi dapat disebabkan oleh proses pencucian yang tidak bersih atau kontaminasi dari air pencucian. Sedangkan minuman dan makanan masak dapat terkontaminasi dari peralatan yang digunakan, air ataupun penjamah makanan. Sampel peralatan dan tangan juru masak dapat terkontaminasi melalui air yang digunakan atau melalui perilaku juru masak yang tidak higienis misalnya tidak mencuci tangan terlebih dahulu sebelum mengolah makanan. Untuk sampel air, jika nilai MPN makin kecil maka kualitas air tersebut semakin baik, sedangkan sarana air bersih dapat terkontaminasi coliform akibat adanya kebocoran pada sistem perpipaan pada penyediaan air bersih (Waluyo, 2009).

Uji lengkap dengan media Methylene Blue Agar (EMBA) digunakan sebagai media selektif untuk mengetahui keberadaan Escherichia coli (E. coli) sebagai bakteri fecal coliform dan Enterobacter aerogenes (E. aerogenes) sebagai bakteri non fekal coliform. Hasil uji lengkap dapat dilihat pada Tabel 4.

Tabel 4. Hasil uji peneguhan pada sampel makanan dari setiap kantin

\begin{tabular}{cccccc}
\hline Sampel & \multicolumn{6}{c}{ Koloni E.Coli yang tumbuh pada media EMBA } \\
& X & A & B & C & D \\
\hline Makanan Masak & - & - & - & - & - \\
Makanan Mentah & - & - & - & - & - \\
Air Minum & - & - & - & - & - \\
Air Keran & - & - & - & - & - \\
Tangan Juru Masak & - & - & - & - & - \\
Peralatan & - & - & - & - & - \\
\hline
\end{tabular}

Hasil uji lengkap menunjukkan bahwa koloni yang tumbuh pada media EMBA berwarna merah muda dan ungu. Hasil ini menunjukkan bahwa sampel mengandung bakteri dari golongan non-fekal. Menurut Suriawiria (2008), bakteri Coliform non-fecal seperti Klebsiela dan Aerobacter memiliki karakteristik seperti E.coli. Bakteri golongan ini memiliki habitat lebih banyak di tanah dan air dibandingkan dengan di usus. Sedangkan E.coli banyak ditemukan pada kotoran hewan maupun manusia (Susanna dan Budi, 2003). Dari hasil uji lengkap, semua sampel dinyatakan negatif terhadap kandungan E.coli sehingga sampel tersebut tidak terkontaminasi oleh kotoran hewan maupun manusia. Hasil ini memenuhi syarat berdasarkan Permenkes RI No 1096/MENKES/PER/VI/2011 yakni angka bakteri E.coli pada sampel makanan, minuman, dan alat makan adalah 0 atau negatif.

\subsection{SALMONELLA SPP.}

Analisa keberadaan Salmonella sp., dilakukan pada jenis sampel yang sama pada analisa Coliform yaitu sampel makanan masak, makanan mentah, minuman, dan karyawan kantin. Proses isolasi 
sampel dilakukan dengan menggunakan media SSA. Respon positif ditunjukkan jika terdapat koloni bening dengan bintik hitam ditengahnya. Hasil isolasi pada media dapat dilihat pada Tabel 5.

Tabel 5. Respon isolasi sampel pada media SSA

\begin{tabular}{cccccc}
\hline \multirow{2}{*}{ Sampel } & \multicolumn{5}{c}{ Kantin } \\
\cline { 2 - 6 } & X & A & B & C & D \\
\hline Makanan Masak & - & + & + & - & - \\
& - & + & - & - & + \\
\hline Makanan Mentah & & + & + & + & + \\
& & + & - & + & + \\
\hline Air Minum & - & - & - & - & - \\
& - & + & - & - & - \\
\hline Karyawan & + & + & - & - & - \\
& - & + & - & - & - \\
\hline \multicolumn{3}{c}{ Keterangan : }
\end{tabular}

(+) terdapat koloni bening dengan hitam ditengah.

(-) tidak terdapat koloni bening dengan hitam ditengah.

Tabel 5 menunjukkan prosentase respon positif dan negatif pada media SSA pada sampel di setiap kantin ( $n=8)$ kecuali kantin $X(n=6)$. Prosentase respon positif tertinggi diperoleh pada kantin A, kemudian kantin D, diikuti oleh kantin B dan C dan X. prosentase respon positif adalah 39\% dari sampel total $(\mathrm{n}=38)$. Uji konfirmasi dilakukan pada sampel yang memiliki respon positif pada media SSA yaitu dengan uji pewarnaan gram. Hasil pewarnaan gram dapat dilihat pada Tabel 6. Bakteri Salmonella sp. merupakan bakteri gram negatif (memberikan warna merah/merah muda) dan memiliki bentuk batang. Warna merah pada pewarnaan gram negatif disebabkan karena kandungan lipopolisakarida yang tinggi pada dinding sel bakteri yang mengalami decolorizing pada saat pemberian alkohol 95\%. Pada pewarnaan awal, kristal violet akan melekat pada lapisan lipopolisakarida dan pada pewarnaan kedua menggunakan safranin akan menghasilkan warna merah yang menunjukkan bakteri gram negatif. Menurut Delost (2015), jika dalam pewarnaan gram menunjukkan gram negatif dan berbentuk batang maka sampel tersebut mengandung Salmonella sp.

Berdasarkan Tabel 6 terdapat enam sampel gram negatif berbentuk batang (Basil), sedangkan sembilan sampel lainnya gram positif berbentuk batang dan bulat (coccus). Sampel makanan yang terdeteksi Salmonella sp. sebagian besar berasal dari kantin A yaitu gado-gado, timun, kubis (pada makanan) dan es susu (minuman). Gado-gado merupakan masakan yang memiliki bahan dasar sayuran. Sayuran terutama sayuran mentah merupakan bahan makanan yang sangat mudah terkontaminasi Salmonella sp. 
Tabel 6. Hasil Pewarnaan Gram

\begin{tabular}{cccccc}
\hline No & & Jenis Sampel & & $\begin{array}{c}\text { Hasil Pewarnaan Gram } \\
\text { (sifat) }\end{array}$ & Morfologi \\
\hline \multirow{3}{*}{1} & \multirow{2}{*}{ Makanan Jadi } & A & Telur & Gram positif & $\begin{array}{c}\text { Coccus } \\
\text { Basil }\end{array}$ \\
& & B & Gado-gado & Gram negatif & Coccus \\
& & Ayam & Gram positif & Basil \\
\hline & & A & Telur & Gram positif & Basil \\
& & & Kubis & Gram negatif & Gasil \\
& & B & Pecel & Gram negatif & Basil \\
2 & Makanan & C & Tomat & Gram positif & Basil \\
& Mentah & & Ayam & Gram positif & Basil \\
& & D & Kubis & Gram positif & Coccus \\
& & & Timun & Gram positif & Basil \\
\hline 3 & Minuman & A & Es susu & Gram negatif & Basil \\
\hline \multirow{2}{*}{4} & \multirow{2}{*}{ Karyawan } & X & Tangan koki & Gram negatif & Basil \\
& & A & Tangan koki & Gram positif & Coccus \\
& & Tangan kasir & Gram positif & Coccus \\
\hline
\end{tabular}

Sumber kontaminasi dapat berasal dari kontaminasi kotoran hewan (pupuk kandang), manusia maupun penggunaan air yang terkontaminasi oleh Salmonella sp. Menurut Siagian (2002), bahan pangan memiliki kemungkinan terkontaminasi oleh mikroorganisma tanah di tempat bahan pangan tersebut tumbuh. Penggunaan air irigasi yang terkontaminasi kotoran hewan, penggunaan pupuk kandang maupun kotoran manusia memiliki risiko terkontaminasi oleh Salmonella sp. (termasuk Salmonella typhi), Shigella dan V. cholerae. Srianta (2003) juga menyatakan bahwa selain faktor kualitas bahan makanan, proses pengolahan makanan termasuk penggunaan alat masak yang tidak bersih dapat menjadi faktor pertumbuhan Salmonella sp. Adam dan Motarjemi (2004) juga menyatakan hal serupa, sementara Pracoyo et al. (2006) menyatakan bahwa penyajian yang kurang higienis juga berpotensi sebagai sumber kontaminasi Salmonella sp. Berdasarkan hasil observasi, kondisi kantin A termasuk katagori buruk dan kurang higienis sehingga potensi kontaminasi sangat besar. Peralatan makanan (piring, sendok, garpu) juga tersimpan dalam keadaan terbuka disamping meja penyajian (prasmanan).

Pada sampel minuman sumber kontaminasi pada minuman bisa disebabkan oleh air yang digunakan terkontaminasi oleh Salmonella sp. Pada pembuatan minuman, ditambahkan es yang tidak diketahui apakah berasal dari air matang atau air mentah. Iqbal dan Chayatin (2009) dalam penelitiannya menyatakan bahwa kontaminasi bakteri dapat disebabkan oleh penggunaan air mentah. Sebaiknya dalam penyediaan air minum atau menu minuman harus berasal dari air yang memenuhi syarat air minum. 
Pada penelitian ini juga dilakukan pengambilan sampel pada tangan pekerja kantin menggunakan cotton swab. Dari semua sampel tangan pekerja sampel terdapat tiga sampel yang memberikan respon postif pada media SSA yaitu pekerja pada kantin X (koki) dan kantin A (koki dan kasir) sedangkan yang menunjukkan pewarnaan gram negatif dengan bentuk batang hanya ditemukan pada sampel koki kantin X. Pekerja kantin (penjamah makanan) merupakan salah satu potensi terjadinya kontaminasi makanan, hal ini disebabkan kurangnya kesadaran penjamah makanan terhadap higiene perseorangan misalnya mencuci tangan dangan baik dan benar sebelum menjamah makanan serta menggunakan sarung tangan pada saat mengolah makanan.

\section{KESIMPULAN}

Studi ini menunjukkan, walaupun setiap kantin telah memiliki peralatan memasak dan dapur serta fasilitas sanitasi, akan tetapi kondisi dan kebersihan kantin yang berada di lokasi FTSP lebih baik dibandingkan dengan Kantin Terpadu. Disamping itu pengetahuan tentang higiene perseorangan dan sanitasi kantin penjamah makanan (pekerja kantin) di lokasi FTSP juga lebih baik dibandingkan dengan Kantin Terpadu. Hasil analisa sampel tentang keberadaan E.Coli menunjukkan bahwa seluruh sampel negatif sehingga memenuhi syarat berdasarkan Permenkes RI no 1096/MENKES/PER/VI/2011. Sedangkan hasil analisa keberadaan Salmonella sp. menunjukkan bahwa $40 \%$ sampel memberikan respon positif pada uji dengan media SSA dan $16 \%$ yang dinyatakan positif mengandung Salmonella sp.

\section{UCAPAN TERIMA KASIH}

Terima kasih kepada DPPM UII yang telah membiayai penelitian ini serta Laboratorium Bioteknologi Lingkungan UII yang telah membantu dalam analisa sampel.

\section{DAFTAR PUSTAKA}

Adam, M. dan Montarjemi, Y. (2004). Dasar-dasar Keamanan Makanan untuk Petugas Kesehatan, EGC, Jakarta.

Badan Pengawas Obat dan Makanan (BPOM) (2015). Informasi Kejadian Keracunan dari 138 Media Massa Online pada Bulan Oktober - Desember 2015. http://ik.pom.go.id/v2015/beritakeracunan/berita-keracunan-bulan-oktober-desember-2015 diunduh pada 7 Maret 2016

Buccheri, C., Casuccio, A., Giammanco, S., Giammanco, M., La Guardia, M., dan Mammina, C. (2007). Food Safety in Hospital: Knowledge, Attitudes and Practices of Nursing Staff of Two Hospitals in Sicily, Italy. BMC Health Services Research, 7: 45. 
Cappuccino, J.G. dan Sherman, N. (2002). Microbiology A Laboratory Manual. Benjamin Cummings, San Francisco, CA.

Delost, M.D. (2015). Introduction to Diagnostic Microbiology for The Laboratory Sciences. Jones and Baretlett Learning: Burlington.

Departemen Kesehatan Republik Indonesia (2000). Standar Pedoman Perawatan Jiwa. Jakarta.

Departemen Kesehatan Republik Indonesia, (2010). Peraturan Mentri kesehatan Republik Indonesia Nomor 492/ MENKES/ PER /IV/ 2010, Tentang Persyaratan Kualitas Air Minum. Jakarta

Departemen Kesehatan Republik Indonesia, (2011). Peraturan Mentri kesehatan Republik Indonesia Nomor 1096 / MENKES/ PER/ VI/ 2011, Tentang Higiene Sanitasi Jasaboga. Jakarta.

EPA Region 9. (1998). Laboratory Standard Operating Procedure guidance. Colilert, Colilert-18 and Colisure Total Coliform and E.coli Water Analysis, Revised July 30.

ILSI Europe. (2012). Tools for Microbiological Risk Assessment.

Iqbal, W. dan Chayatin, N. (2009). Ilmu Kesehatan Masyarakat. Jakarta: Salemba Medika.

Keputusan Menteri Kesehatan No.924/Menkes/SK/VII/2003 tentang Pedoman Persyaratan Hygiene Sanitasi Makanan Jajanan

Lawley, R., Curtis, L., dan Davis, J. (2008). The Food Safety Hazard. London: RSC Publishing.

Medeiros, L. C., Hillers, V.N., Kendall, P., Mason, A. (2001). Food Safety Education: What Should We Be Teaching To Consumers?. Journal of Nutrition Education 33 (2): 108-13.

Mirawati, M., Lestari, E., dan Djajaningrat, H. (2013). Identifikasi Salmonella Pada Jajanan Yang Dijual Di Kantin Dan Luar Kantin Sekolah Dasar. Jakarta.

Miskimin, D. K., Berkowitz, K.A., Solberg, M., Riha, W.E., Franke, W.C., Buchanan, R.L., O’leary, V. (1976). Relationships between Indicator Organisms and Specific Pathogens in Potentially Hazardous Foods. Journal of Food Science 41 (5): 1001-6.

Pracoyo, N.E, Wati, M, Sugiarningsih, S, Triyani, Syamsidar, Rochayani, S. (2006). Hiegiene Makanan Siap saji pada Beberapa Tempat Pengolahan Makan di DKI Jakarta. Majalah Kesehatan Masyarakat (Journal of Public Health), No. 72, Departemen Kesehatan RI, Jakarta. Roberts, D., Greenwood, M. (2003). Practical Food Microbiology. Blackwell.

Siagian, A., (2002). Mikroba Patogen pada Makanan dan Sumber Pencemarannya. Fakultas Kesehatan Masyarakat. Universitas Sumatera Utara. 
Srianta, (2003). Deteksi Salmonella pada Nasi Goreng yang Disediakan oleh Restoran Kereta Api Kelas Ekonomi. Jurnal Teknologi dan Industri Pangan. Program Studi Teknologi Pangan. FATETA. Universitas Katolik Widya Mandala Surabaya. Surabaya. Hal. 254

Standard Method (1998). 9223 B. Enzyme Substrate Test. 20th ed., rev.

Suriawiria, U. (2008). Mikrobiologi Air dan Dasar-dasar Pengolahan Buangan Secara Biologis. Bandung: PT Alumni

Susanna, D., Budi H., (2003). Pemantauan Kualitas Makanan Ketoprak dan Gado-gado di Lingkungan Kampus UI Depok, Melalui Pemeriksaan Bakteriologis. MAKARA, Seri Kesehatan, Vol. 7-1

Suwandono, A.M. Destri dan Simanjuntak, C., (2005). Salmonellosis dan Surveillans demam tifoid yang disebabkan Salmonella di Jakarta Utara. Disampaikan dalam Lokakarya Jejaring Intelijen Pangan - BPOM RI, Jakarta, 25 Januari 2005.

Tarwoto, Wartonah. (2004). Kebutuhan Dasar Manusia dan Proses Keperawatan. Edisi ketiga. Jakarta : Salemba Medika.

Waluyo, L. (2009). Mikrobiologi Lingkungan. Malang: Universitas Muhammadiyah Malang Press.

Walker, E., Pritchard, C. dan Forsythe. S. (2003). Food Handlers' Hygiene Knowledge in Small Food Businesses. 14: 339-43. 